УДК (477)94(470) «1863-1864»

\title{
СКРИПНИК А.Ю.
}

https://orcid.org/0000-0002-3812-918X

https://doi.org/10.33577/2313-5603.31.2019.53-68

\section{ВІЙСЬКОВО-ПОЛІТИЧНІ ЗАХОДИ РОСІЙСЬКОЇ ВЛАДИ ПЕРЕД СІЧНЕВИМ ПОВСТАННЯМ 1863 - 1864 pp.}

У статті розглянуто приготування російського царату, спрямовані на відвертання польського Січневого повстання на теренах Правобережної України. Висвітлено загальну політичну ситуацію у краї, проаналізовано причини протиріч між соціальними прошарками і групами. Крізь призму соціальних настроїв у Південно-Західному краї Російської імперії досліджено рівень готовності адміністративно-мілітарних керівних структур Київського генерал-губернаторства до «антидержавницьких дій», простежено створення при губернських і надгубернських установах оперативних відділів моніторингу настроїв серед населення та впливу зовнішніх факторів. Встановлено міру ефективності залучення частин регулярного війська щодо запобігання збройним виступам та їх використання у якості поліцейських підрозділів. Окремо з'ясовано ставлення місцевого населення (зокрема, українського селянства) до повстанців, сприйняття й потрактування ними їхніх програмних політичних цілей і прагнень. Показано реакцію європейських країн на події у Царстві Польському та на заході Російської імперії, простежено вірогідність їх мілітарного втручання 3 метою локалізації репресивних дій російського самодержавства. Представлено об'єктивні і суб'єктивні причини поразки польського патріотичного повстання та її наслідки для мешканців регіону.

Ключові слова: Київське генерал-губернаторство, соціально-політичне становище, Січневе повстання, російська армія.

Постановка проблеми та ії актуальність. Із втратою незалежної держави наприкінці XVIII ст. польський етнос упродовж першої половини наступного століття жив мріями і планами про іiі відродження, вважаючи єдиним шляхом досягнення своєї мети збройне повстання. Колонізатором і поневолювачем була імперія Романових, яка намагалася асимілювати поляків, втягнути їх до загальноімперського простору, знищивши національні ознаки та ідентичність. Перші два збройні повстання, у 1794 р. під проводом Т. Костюшка та Листопадове повстання 1830 - 1831 рр., закінчилися поразками через перевагу росіян у міліарній організації (Скрипник, 2016).

Скрипник Анатолій Юрійович, доктор історичних наук, доцент, завідувач кафедри інформаційної діяльності, документознавства і фундаментальних дисциплін Подільського спеціального навчально-реабілітаційного соціально-економічного коледжу, м. Кам'янець-Подільський.

() Скрипник А.Ю., 2019 
Однак знищити саму думку поляків про відновлення власної держави їм остаточно не вдалося.

Разом 3 тим змінювалася й сама імперія. Після поразки у Східній (Кримській) війні 1853 - 1856 рр. вона ступила на шлях реформ. Одним з інститутів держави, який зазнав докорінних змін, стала імператорська армія. Відмовившись від старої кріпосницької моделі, керівництво намагалося надати їй новітніх форм: перевага якості над кількістю, реформа навчальних закладів, модернізація озброєння $\mathrm{i}$, нарешті, докорінно новий територіальний принцип розташування (дислокації) - військові округи, що дало можливість остаточно поєднати адміністративні й військові повноваження. На початку 60-х років XIX ст. ці два чинники вкотре вступили в історичне протиріччя.

Мета і завдання дослідження. Проблематика подій 1863 1864 pр. на теренах Правобережної України не втрачає своєї актуальності й досі. Сучасні українські дослідники, використовуючи архівні матеріали, активно вивчають різноманітні аспекти польського визвольного руху та його вплив на соціальні реалії регіону. Свідченням важливості $є$ проведення наукових конференцій, семінарів, круглих столів тощо. 9 листопада 2018 р. в стінах НIAМ «Київська фортеця» пройшла Міжнародна конференція, присвячена Січневому повстанню, за участю фахівців з України та Польщі. Одним із наукових векторів залишається мілітарний чинник. Відомо, що приготування тривали одночасно з обох сторін і мали характер планомірної підготовки, яка потім переросла у партизанську війну повстанців проти російської армії і поліції.

Аналіз попередніх досліджень $і$ публікацій. Події Січневого повстання виявилися завершальним циклом збройної боротьби поляків за незалежність у XIX ст., давши історикам чимале поле для досліджень та аналізу подій у політичній, соціальній та військовій площині. За останні більш ніж сто років нагромаджено чималий джерельний масив, видано десятки праць.

Усвідомлення польською нацією зникнення іï держави з політичної карти Свропи, зокрема й насильницьке захоплення «східних кресів», послужило потужним імпульсом до національно-патріотичної боротьби протягом більш ніж 100 років. Цей насичений і драматичний період мотивував детальне вивчення політичних, військових та соціальних подій у краї представниками історичної школи XIX ст. i сучасними дослідниками. Тому праці, присвячені подіям Січневого повстання, є досить численними. Його причини, рушійні 
сили, перебіг подій та результати науково систематизовані, пояснені низкою дослідників 3 широким використанням архівних матеріалів та спогадів самих учасників. Серед фахівців такої проблематики варто згадати комплексну колективну працю С. Києневича, А. Загорського та В. Заєвського (Kieniewicz, Zahorski and Zajewski, 1992), а також наукові здобутки Т. Гасовського (Gqsowski, 2016), Т. Кізвальтера (Kizwalter, 1999), Б. Томашевського (Tomaszewski, 2006). Польські вчені продовжують перебувати в авангарді сучасної європейської історіографії вивчення минулого Правобережної України. Однак все активніше до наукових студій долучаються й українські історики. Використовуючи переважно архівні джерела часів Російської імперії, до їх поля наукового зору потрапляє перебіг подій в окремих повітах та факти спільної боротьби поляків і українців проти російських колонізаторів. Потужним рушієм дослідження Січневого повстання стали спільні наукові проекти. Наприклад, колективна монографія за редакцією I. Кривошеї й Н. Моравця (Кривошея\&Моравиьь, 2014) та документально-історичне есе Д. Кулиняка й І. Дерека (Кулиняк\&Дерек, 2018), в яких висвітлено події повстання, розкрито передісторію та перебіг подій, значна увага сфокусована на діях російської влади як репресивному чинникові.

Виклад основного матеріалу. 3 літа 1861 р., крім турбот з реалізації селянської реформи, в російської адміністрації краю з'явилася ще одна перспективна проблема. Все частіше жандарми доповідали губернаторам і Київському генерал-губернатору I. Васільчікову про посилення патріотичних і бунтівних настроїв серед частини населення Правобережжя. Судячи зі всього, назрівало ще одне польське повстання: розповсюджувалася заборонена література, вербувалися майбутні бійці повстанських загонів, збиралися кошти на придбання зброї, відбувалися маніфестації, демонстративні святкування таких подій, як Люблінська унія, Конституція 3-го травня, співи заборонених патріотичних пісень, «котяча музика» під вікнами колабораціоністів (Дьяков, 1993:136). Тільки у серпні-вересні 1861 р. на теренах Київського генерал-губернаторства поліцією і жандармами було зафіксовано близько 45 подібних демонстрацій (Зашкільняк\&Крикун, 2002: 327).

Керівництво повстанців було налаштовано досить рішуче: «Народ згоден проливати кров, тому що прагне політичного бунту, тому що хоче незалежності, хоче бути вільним. Геть царські милості, ми взялися до зброї, і тільки зброя вирішить наше протистояння з Москвою!» - йшлося у відозві ватажків (Dokumenty 
Komitetu Centralnego Narodowego i Rzqdu Narodowego 1862 - 1864, 1968:99). Намагаючись не допустити загострення ситуації в Польщі, у Петербурзі лібералізували умови селянської реформи 1861 р. та водночас намагалися залучити українське селянство на свій бік у боротьбі з польським національно-визвольним рухом. (Секретное предписание генерал-губернатору Юго-западного края, генералу Анненкову Николаю Николаевичу о военно-полицейских мероприятиях 1863 г., л. 3).

Виявилося, що це не так важко зробити. Зверхнє ставлення пихатої шляхти до своїх кріпаків та відмова надати їм реальну свободу локалізували повстання. Егоїзм польського дворянства зумовив його поразку, а рішення петербурзької адміністрації кардинально і швидко, без періоду тимчасовозобов'язаного стану селян, здійснити поземельну реформу остаточно позбавило заколот підтримки. Саме під впливом національного повстання 1863 р. наділи українських і польських селян були збільшені у Київській губернії на 28,9\%, у Подільській - на 26,4\% і у Волинській - на 21,2\% (Костюшко, 1962:271). На думку російського історика Ю. Зельдича, «Самодержавство чудово використало ситуацію у своїх політичних цілях, вбивши клин між польською шляхтою та українським селянством, який витягнути було вже неможливо» (Зельдич, 2006:211).

Реакцією на потенційні загрози стало поступове впровадження запобіжних заходів військового характеру. В апаратах київського і віленського генерал-губернаторів було встановлено цілодобове чергування спеціальних старших ад'ютантів та особистих ад'ютантів, а їм на допомогу призначали обер-офіцерів чином не нижчим за підполковника зі штабів корпусів (ПСЗРИ 1. № 37227). До них надходила уся оперативна інформація щодо загального становища у краї, яку вони негайно доводили до відома начальників.

На початку серпня 1862 р. у Петербурзі не виключали можливість запровадження військового стану в західних губерніях. Однак, надали можливість генерал-губернаторам самим вирішувати, коли його вводити і де саме, не озираючись на царя чи міністрів. Разом 3 тим, окремим указом були регламентовані права і повноваження представників влади на випадок легітимізації мілітарного чинника. Вони були подібні до тих, які запроваджувалися під час повстання 1830 - 1831 рр.: вся влада належала військовим, беззаперечне кадрове підпорядкування чиновників губернських і повітових установ, 
арешти підозрілих, судові переслідування, повний контроль поліції над суспільно-економічним життям, можливість застосування владою зброї (ПСЗРИ 2 , № 37328).

У зв'язку з початком посилення соціально-політичної напруги в Царстві Польському та небезпекою вибуху другого польського патріотичного повстання російське самодержавство розпочало військові приготування, територія краю поступово наповнилася військами. Обидві сторони формували і накопичували сили, а на початку лютого 1863 р. з Правобережжя до Польщі вступили частини військ Київського військового округу (Скрипник, 2016:411). Як і в 1794 p. та 1831 р., росіяни робили все для того, щоб повстання не поширилося на терени Київського генерал-губернаторства. За наказом командувача військами округу для захисту Волинської губернії був направлений загін на чолі з генерал-лейтенантом Рудановським. Одна частина під його особистим командуванням прикривала Волинь з боку Литви (Гродненської і Мінської губерній) на ділянці від Ратно до річки Горинь. Друга частина - під командуванням генерал-ад'ютанта графа Ржевудського прикривала південний кордон та західну частину Волині. Крім свого головного призначення з охорони меж губернії, обидва загони зобов'язали допомагати військам на території Люблінського відділу у пошуках загонів повстанців (Гескет, 1894:19).

Завдяки жандармській агентурі вищому керівництву стали відомі подробиці початку повстання. У грудні 1862 р. київський генерал-губернатор надіслав губернаторам секретний циркуляр про близький початок «польського бунту». В ньому повідомлялося, що повстання може розпочатись наприкінці грудня цього ж року, надсилався малюнок зразка таємного знаку, за яким змовники мали впізнавати один одного. Наголошувалося, що кожен повстанець має присягнути на вірність Польщі й по можливості залучити якнайбільшу кількість учасників (Циркуляр Київського генералгубернатора начальникам губерній грудень 1862 р., арк. 7-8). За розпорядженням подільського губернатора у прикордонних містечках та селах були введені посилені патрулі, важливі об'єкти в містах взяті під охорону, на вулицях, окрім поліцейських, чергували воєнні патрулі. 3 метою перешкоджання проникненню повстанців 3 території Австрії на всіх поромних переправах через Дністер виставили військові пости, а берег патрулювали кінні роз'їди, сформовані з місцевих селян (Про патрулі в повітах і поліційній охороні грудень 1862 р., арк. 38). На літо 1863 р. російський уряд 
істотно збільшив кількість військ у самій Польщі й Західному краї, тобто у Білорусі, Литві та Правобережній Україні (Циркулярний припис Київського військового, Подільського і Волинського генералгубернатора про призначення його командиром окремого корпусу для боротьби з польськими революиіонерами., арк. 1 - 3; 38-39).

Намагаючись діяти на випередження, київський генералгубернатор кн. І. Васільчіков наприкінці серпня 1862 р. отримав право на впровадження військових судів, які могли судити за «Польовим карним положенням» осіб, обвинувачених у безладах і бунтах, що призвели до введення військового стану, протягом 24 годин, а вироки виконувати одразу ж (ПСЗРИ 3, № 37370). Такі заходи мали на меті залякати бажаючих виступати проти існуючого державного ладу та дати більше можливостей і свободи дій репресивній машині у справі нівелювання хвилі соціального піднесення та революційних настроїв у польському суспільстві.

Ще одним превентивним заходом росіян, який явно недооцінило польське політичне керівництво, стало створення з військ 1-ї Армії та 1-го, 2-го і 3-го армійських корпусів на теренах потенційного ареалу повстання трьох військових округів: Варшавського, Віленського та Київського, з метою зосередження усієї повноти військової влади в руках генерал-губернаторів у зонах їх відповідальності (ПСЗРИ 4, № 38452). Наступним кроком проти поляків було несподіване оголошення самодержавством у вересні 1862 р. чергового рекрутського набору, призначеного на початок 1863 p. (ПСЗРИ 5, № 38622). «За цим законом конскрипти (новобранці A. C.) у кількості близько 10 тис. осіб мали бути призвані виключно 3 міського населення. Цей набір припадав на бойову силу заколоту і мав завдати організації чималої шкоди» (Гескет, 1894:8). Тому значна частина польської молоді призовного віку покидала міста підросійської Польщі і гуртувалася в лісах. Польські історики сходяться на думці, що саме ці фактори стали передчасними спонукальними імпульсами для виступу у Царстві Польському (Kieniewicz, Zahorski and Zajewski, 1992:584).

Такі подальші події, як хід повстання та заходи з його придушення, не тільки спонукають до висновків про потенційну перевагу імперської воєнної машини над патріотичними потугами поляків, а й складають враження, по-перше, певної моральної готовності та віри у свої сили адміністративних органів влади за підтримки 
військового командування; по-друге, збіг у часі аграрних перетворень та повстання створив для влади сприятливі умови. Серед таких дещо несподіваних збігів була підтримка влади українськими селянами, які під керівництвом офіцерів штабу Київського військового округу створювали селянські сторожі, що протидіяли повстанцям (Шандра, 2014:106).

Історичний парадокс полягав у тому, що коли почалося повстання, українські селяни - недавні дестабілізатори соціальних змін кинулися допомагали російським військам усіма силами: виловлювали одинаків-інсургентів, захоплювали та конвоювали полонених $\mathrm{i}$ навіть вступали у сутички (Переписка з 9-ю артилерійською бригадою про отримання зброї сільською сторожею в Бращлавському $i$ Винницькому повітах, червень 1863 р. арк. 22 - 24). «Під Києвом, біля сіл Ковалівка і Пологи, загін озброєних селян на чолі з волосним старшиною І. Шадуром оточив групу повстанців. Погрожуючи знищенням, вони кричали: «Здавайтеся, а то ми вас зв'яжемо, як вже багатьох таких пов'язали». Ті почали втікати, але селяни переслідували їх наче мисливські собаки. В селах били у дзвони, палали багаття, ламалися містки через потічки та мочарі на шляху поляків» (Позанский, 1885:450). Часто організаторами і ватажками селянських загонів ставали відставні чи безтерміново-відпускні солдати й унтер-офіцери. Вони діяли разом з підрозділами регулярних військ та переслідували й розшукували повстанців 3 не меншою завзятістю, ніж драгуни (Позанский, 1885:572). У селі Солов'ївка Радомишльського повіту Київської губернії загін польських революціонерів у кількості 21 особи був оточений і жорстоко повністю перебитий селянами, які діяли виключно сокирами та кілками (Берг, 1879:55). Таке ставлення до своїх поміщиків стало дещо несподіваним для російської влади. Волинський військовий губернатор князь М. Друцкой-Соколинський із задоволенням доповідав до Петербурга: «Усюди, де піднімали голову заколотники, як-то в повітах: Житомирському, Новоград-Волинському, Заславському, Острозькому та Овруцькому - вони отримували відсіч з боку сільського населення, - населення мирного, але натхненного подякою Царю-Визволителю і відданістю уряду. Нехтуючи небезпекою, вони хапали десятками озброєних повстанців і приводили до начальства» (Aйрапетов, 2013:69). Маючи такого союзника на місцях, вище керівництво імперії зосередилося на придушенні 
повстання у самому Царстві Польському, Білорусі та Литві. Переважна більшість боєздатних військ, а це дивізії Гвардійського та Гренадерського корпусів, були направлені саме туди.

Разом 3 тим, ноти протесту західноєвропейських держав щодо польського питання почали переростати у серйозні приготування до війни. Розуміючи це, генерал Д. Мілютін писав, що „Війна 3 коаліцією європейських держав у цей час була б для нас загибеллю. Наші військові сили не готові до війни, по усіх частинах щойно розпочаті перетворення і розробка нової організації армії». Незважаючи на збільшення за півроку повстання кількості військ у Європейській Росії на 167 тисяч і доведення зального числа до 690 тисяч вояків при 1026 гарматах, 3 яких у Варшавському, Віленському i Київському військових округах знаходилося 342 тисячі при 410 гарматах, боєздатність військ була низькою. Небезпека зіткнення 3 колишніми супротивниками по Кримській війні та отримання чергової поразки були реальними (Редигер, 1900:245). Втім, повстання вдалося спочатку локалізувати, а потім і ліквідувати, використовуючи виключно наявні військові частини. Разом з поліцейськими вони проводили масовані обшуки в маєтках підозрюваних поміщиків за доносами селян. Неподалік від житлових і господарських будівель знаходили приховану вогнепальну зброю, свинцеві кулі, дріб, картеч, шаблі, кінські сідла та кіраси. Солдатів всіляко заохочували до сумлінного виконання своїх обов'язків, місцеві мешканці часто допомагали викрити такі схованки, щоб помститися своїм господарям (Переписка з Подільським губернатором щзоо осіб, які брали участь у польському повстанні листопад 1863 р., арк. 1-2; 29).

Висновки. Важливим чинником дослідження Січневого повстання стає неупереджений аналіз загальної боєздатності загонів повстанців та їх спроможності протистояти регулярним військам. На думку польського дослідника Я. Бартизеля, «Повстання одразу ж стало parexcellence, тобто нерегулярним бродінням, яке то зростає, то слабшає і перетворюється на партизанську війну. Ця війна імпровізована, вона триває в лісі, а не у відкритому полі, без вищого командування, штабу і плану, здійснюється добровольцями, які не мають військової освіти. Її зміст - це сутички, а не битви регулярних тактичних з'єднань. Такий характер малої партизанської війни геррильї, яка тривала проти регулярної армії найбільш потужної країни тодішньої Європи, - 3 самого початку мав вражаючу диспропорцію власних сил та сил ворога» (Бартызель, 2013:179). Такі об’ єктивні підстави зумовлювали й поразку. Якщо перемогу 
не здобула тридцять років тому добре вишколена й озброєна регулярна армія Царства Польського, то яким дивом це могли зробити слабкі лісові загони з примітивною холодною зброєю?

\section{Використані посилання}

Gąsowski T. 2016. Konsekwencje powstań narodowych $w$ XIX wieku dla polskiej tożsamości narodowej. SCIAGA.pl. [online] Доступно: <http://sciaga.pl/tekst/58014-59-sens_powstan_ narodowych_ w_xix_wieku> [Дата звернення 12 травня 2016].

Kieniewicz S., Zahorski A., Zajewski W. 1992. Trzy powstania narodowe: kościuszkowskie, listopadowe, styczniowe. Warszawa: PWN, s. 671.

Kizwalter T. 1999. O nowoczesności narodu: przypadek polski. Warszawa. s. 229.

Komitet Centralny jako Rząd Narodowy. 1968. Dokumenty Komitetu Centralnego Narodowego i Rządu Narodowego 1862-1864. Wrocław, s. 99.

Tomaszewski B. 2006. Źródła narodowości. Powstanie i rozwój polskiej świadomości w II połowie XIX i na początku XX wieku. Wrocław: Wydawnictwo Uniwersytetu Wrocławskiego, s. 397.

Айрапетов О. Р. 2006. Внешняя политика Российской империи (1801-1914). Москва: Европа, 245 с.

Бартызель Я. 2013. 1863 - вместе в пропасть. В: О. Р. Айрапетов, ред. Русский сборник: исследования по истории России, том XV. Москва, с. 179.

Берг Н. В. 1879. Польское восстание в 1863-1864 гг. Русская старина. Том XXV. Вып. 7. С. Петербург: с. 55.

Гескет С. 1894. Военные дейсвия в Царстве Польском в 1863 году. В: Пузыревский, ред. Начало восстания (Январь, Февраль и первая половина Марта). Глава Х. Варшава: с. 401.

Дьяков В.А., ред. 1993. Краткая история Польши. С древнейших времен до наших дней. Москва: с. 136.

Зашкільняк Л., Крикун М. 2002. Історія Польщзі: від найдавніиих часів до наших днів. Львів, с. 326-328.

Зельдич Ю. В. 2006. Петр Александрович Валуев и его время: Историческое повествование. Москва: Аграф, с. 576.

Костюшко И. И. 1962. Крестьянская реформа 1864 года в Царстве Польском. Москва: изд-во АН СССР, с. 271. 
Кривошея I., Моравець Н., ред. 2014. Польське національне повстання 1863-1864 рр. на Правобережній Україні: від міфів до фактів. Умань: ФОП Жовтий О.О., с. 184.

Кулиняк Д., Дерек I. 2018. За нашу і вашу свободу. Документально-історичне есе. Київ: Саміт-Книга, с. 112.

Переписка 3 9-ю артилерійською бригадою про отримання зброї сільською сторожею в Брацлавському і Винницькому повітах. Державний архів Житомирської області, Ф. Д-701, (Штаб Тульчинського військового загону Київського військового округу), Оп. 1, Спр. 2, Арк. 22-24.

Переписка з Подільським Губернатором щодо осіб, які брали участь у польському повстанні. Державний архів Хмельнииької області. Ф. 634. (Кам’янець-Подільська військово-слідча комісія). Оп. 1. Спр. 2. Арк. 1-2; 29.

Позанский Б. 1885. Воспоминания о польском восстании в Украине 1863 г. Киевская старина. Том ХIII. Київ: с. 450; 455.

Про патрулі в повітах і поліційній охороні. Колишній Кам'янещьПодільський державний міський архів. Ф. 228. (Канщелярія Подільського губернатора), Оп. 1. Спр. 3476. Арк. 38.

ПСЗРИ 1. Закон № 37227. О разрешении иметь в Дежурствах некоторых Начальников губерний Старших Адъютантов в штабофицерских чинах до Подполковника включительно. В: Полнылй свод законов Российской империи (далі-ПСЗРИ-ІІ). С. Петербург: Тип. ІІ Отд. Соб. Е.И.В. канц., 1863. Т. XXXVI. Отд. 2. с. 138.

ПСЗРИ 2. Закон № 37328. О правилах на случай объявления каких-либо местностей Западных губерний на военном положении. В: ПСЗРИ-ІІ. С Петербург: Тип. II Отд. Соб. Е.И.В. канц.,1863. Т. XXXVI. Отд. 2. с. 225-226.

ПСЗРИ 3. Закон № 37370. О представлении Главным Начальникам Западных губерний права предавать военному суду, по Полевому Уголовному Уложению, виновных в беспорядках, подавших повод к объявлению каких-либо местностей в военном положении и приводить приговоры о них в исполнение немедля. В: ПСЗРИ-ІІ. С. Петербург: Тип. II Отд. Соб. Е.И.В. канц., 1863. Т. XXXVI. Отд. 2. с. 251-252.

ПСЗРИ 4. Закон № 38452. Высочайше утвержденное Положение о Главном Управлении войсками входящими ныне в состав 
1-й Армии. В: ПСЗРИ-ІІ. С Петербург: Тип. II Отд. Соб. Е.И.В. канц., 1865. Т. XXXVII. Отд. 1. с. 660-664.

ПСЗРИ 5. Закон № 38622. О производстве в 1863 году рекрутского набора с обеих полос Империи. В: ПСЗРИ-ІІ. С. Петербург: Тип. II Отд. Соб. Е.И.В. канц., 1865. Т. XXXVII. Отд. 2. с. 1-4.

Редигер А. Ф. 1900. Комплектование и устройство вооруженной силь. Изд. третье. Санкт-Петербург: Военная типография (Издание Главного штаба), с. 576.

Секретное предписание генерал-губернатору Юго-западного края, генералу Анненкову Николаю Николаевичу о военно-полицейских мероприятиях. В: Российский государственный архив древних актов. Ф. 1468 (Сборный личный фонд), Оп. 1, Д. 60. Л. 1-3.

Скрипник А. Ю. 2016. Російський військовий чинник у суспільно-політичному та економічному розвитку Правобережної України (1792-1865рр.), Кам'янець-Подільський: вид. ФОП Зволейко Д. Г., с. 612.

Скрипник А. Ю. 2018. Мілітарне протистояння у Листопадовому повстанні 1830-1831 pр. на Правобережній Україні. Військовонауковий вісник Академії сухопутних військ імені гетьмана Петра Сагайдачного. Вип. 30. Львів: НАСВ, с. 47-60.

Циркуляр Київського генерал-губернатора начальникам губерній. Колишній Кам'янещь-Подільський державний міський архів. Ф. 228. (Канцелярія Подільського губернатора), Оп. 1. Спр. 3347. Арк. 7-8.

Циркулярний припис Київського військового, Подільського і Волинського генерал-губернатора про призначення його командиром окремого корпусу для боротьби з польськими революціонерами. Державний архів Хмельнищької області. Ф. 123. (Подільський губернський предводитель дворянства). Оп. 1. Спр. 281, Арк. 1-3; 38-39.

Шандра В. С. 2014. Соціальні і політичні наслідки для України польського Січневого повстання 1863 року. Вип. 1. (№ 514) УІЖ, c. 106. 


\section{REFERENCES}

Gąsowski T. 2016. Consequences of national uprisings in the 19th century for the Polish national identity. SCIAGA.pl. [online] Available at: <http://sciaga.pl/tekst/58014-59-sens_powstan_ narodowych_ w_xix_wieku> [Accessed 12 May 2016] (pl).

Kieniewicz S., Zahorski A., Zajewski W. 1992. Three national uprisings: Kościuszko, November, January. Warsaw: PWN, p. 671 (pl).

Kizwalter T. 1999. On the modernity of the nation: the Polish case. Warsaw, p. 229 (pl).

Central Committee as the National Government. 1968. Documents of the National Central Committee and National Government 18621864. Wroclaw, p. 99 (pl).

Tomaszewski B. 2006. Sources of nationality. Establishment and development of Polish consciousness in the second half of the 19th and the beginning of the 20th century. Wrocław: Publisher of the University of Wrocław, p. 377 (pl).

Airapetov O. R. 2006. Foreign Policy of the Russian Empire (18011914). Moscow: Europe, p. 245 (rus).

Bartyzel I. 2013. 1863 - together into the abyss. In: O.R. Airapetov, ed. Russian collection: research on the history of Russia, vol. XV. Moscow, p. 179 (rus).

Berg N.V., 1879. Polish uprising in 1863-1864. Russian olden times. Vol. XXV. Issue 7. St. Petersburg: p. 55 (rus).

Gesket S. 1894. Military actions in the Kingdom of Poland in 1863. In: Puzyrevsky, ed. The beginning of the uprising (January, February and the first half of March). Chapter X. Warsaw: p. 401 (rus).

Dyakov V. A., ed. 1993. A brief history of Poland. From ancient times to the present day. Moscow: p. 136 (rus).

Zashkilnyak L., Krykun M. 2002. History of Poland: from ancient times to the present day. Lviv, p. 326-328 (ukr).

Zel'dich Yu. V. 2006. Pyotr Aleksandrovich Valuev and His Time: A Historical Narrative. Moscow: Agraf, p.576 (rus).

Kostyushko I. 1962. The peasant reform of 1864 in the Kingdom of Poland. Moscow: Publishing House of the Academy of Sciences of the USSR, p. 271 (rus). 
Krivosheya I., Moravets N., ed. 2014. Polish national uprising of 1863-1864 in the Right-Bank Ukraine: from myths to facts. Uman: FOP Zhovtyy O.O., p. 184 (ukr).

Kulinyak D., Derek I. 2018. For our and your freedom. Documentary-historical essay. Kyiv: Summit Book, p. 112 (ukr).

Correspondence from the 9th artillery brigade on the acquisition of weapons by the village guard in the Bratslav and Vinnitsa counties. State Archive of Zhytomyr Region, F. D-701, (Tulchinsky Headquarters Military Detachment of the Kyiv Military District), Op. 1, Sp. 2, Arch. 22-24 (ukr).

Correspondence with the Podilsky Governor regarding the persons who participated in the Polish uprising. State Archives of Khmelnitsky Region. F. 634. (Kamyanets-Podilsky Military Investigation Commission). Op. 1. Sp. 2. Arch. 1-2; 29 (ukr).

Pozansky B. 1885. Memories of the Polish uprising in Ukraine 1863. Kiev olden times. Volume XIII. Kyiv: s. 450; 455 (rus).

About patrols in counties and police guards.Former KamyanetsPodilsky State Urban Archive. F. 228. (Office of Podilsky Governor), Op. 1. Sp. 3476. Arch. 38 (ukr).

CSLRE 1. Law No. 37227. About permission to have on duty some Chiefs of Provinces of Senior Adjutants in headquarters ranks up to Lieutenant Colonel inclusive. In: A complete set of laws of the Russian Empire (hereinafter - CSLRE-II). St. Petersburg: Type. II Dep. Sob. E.I.V. office, 1863. T. XXXVI. Department 2. p. 138 (rus).

CSLRE 2. Law No. 37328. On the rules in case of declaring any areas of the Western provinces in a state of martial law. In: CSLRE-II. St. Petersburg: Type. II Dep. Sob. E.I.V. office, 1863. T. XXXVI. Department 2. p. 225-226 (rus).

CSLRE 3. Law No. 37370. On the submission to the Chief Superior of the Western Provinces of the right to bring to the military court, according to the Field Criminal Code, the perpetrators of the unrest, giving rise to the declaration of any areas in a state of war and to execute sentences about them immediately. In: CSLRE-II. St. Petersburg: Type. II Dep. Sob. E.I.V. office, 1863. T. XXXVI. Department 2. p. 251-252 (rus).

CSLRE 4. Law No. 38452. The Highest Approved Regulations on the Main Command and Control of the Troops that are now part of the 1st Army. In: CSLRE-II. St. Petersburg: Type. II Dep. Sob. E.I.V. office, 1865. T. XXXVI. Department 2. p. 660-664 (rus). 
CSLRE 5. Law No. 38622. On the production in 1863 of recruitment from both lanes of the Empire. In: CSLRE-II. St. Petersburg: Type. II Dep. Sob. E.I.V. office, 1865. T. XXXVI. Department 2. p. 1-4 (rus).

Rediger, A. F. 1900. Manning and organisation of armed forces. Third Ed. St. Petersburg: Military Printing House (Edition of the General Staff), p. 576 (rus).

Secret order to the Governor-General of the South-Western Territory, General Annenkov Nikolai Nikolayevich on military and police activities. Q: Russian State Archive of Ancient Acts. F. 1468, (Composite Personal Fund), Op. 1, D. 60. L. 1-3 (rus).

Skrypnyk A. Yu. 2016. Russian military factor in the socio-political and economic development of the Right-Bank Ukraine (1792-1865) Kamenetz-Podilsky: publishing house of the FOP Zvolejko D.G., p. 612 (ukr).

Skrypnyk A. Yu. 2018. Militaristic confrontation in the November uprising of 1830-1831 in the Right-Bank Ukraine. Military Scientific Herald of the National Hetman Petro Sagaidachny Army Academy. Issue 30. Lviv: NAA, p. 47-60 (ukr).

Circular of the Kiev Governor-General to the heads of the provinces. Former Kamyanets-Podilsky State Urban Archive. F. 228. (Office of Podilsky Governor), Op. 1. Sp. 3347. Arch. 7-8 (ukr).

The Circular Order of the Kyiv Military, Podilsky and Volyn Governor-General on the appointment of his commander of a separate corps to fight the Polish revolutionaries. State Archives of Khmelnitsky Region. F. 123. (Podilsky provincial leader of the nobility). Op. 1. Sp. 281, Arch. 1-3; 38-39 (ukr).

Shandra V.S. 2014. Social and political implications for Ukraine of the Polish January uprising of 1863. Issue 1. (No. 514) UIZ, p. 106 (ukr).

Skrypnyk A.

MILITARY AND POLITICAL PRECAUTIONS OF THE RUSSIAN AUTHOTITY BEFORE THE JANUARY REVOLT OF 1862-1863

The paper considers the Russian tzarist's precautions against Polish January rebellion in Right-Bank Ukraine, reveals general political situation in the region, analyzes reasons of conflicts between social strata and groups. 
The overall political situation in the Russian Empire serves the background of the research of administrative and military bodies of Kyiv province preparations against the «antigovernment revolts». The author states that within the provincial authority bodies and institutions of higher subjectivity, the departments whose functions included investigation of social opinions and interference of external factors were formed. Besides, the effectiveness of regular army units used to combat armed revolts and their police functions as well as local citizens' (Ukrainian peasants in particular) attitude towards the rebels, interpretation and perception of the latters' political goals and strivings are outlined. The research reveals the reaction of the European countries to the events in the Polish Kingdom and in the west of the Russian Empire, probability of their military interference in order to limit the Russian autocracy's repressive actions, objective and subjective reasons of the Polish patriotic rebellion defeat and its effect upon the local population.

After the loss of state independence in the late $18^{\text {th }}$ century, during the first half of the next century the Poles dreamt and planned its revival where the only way to reach this goal was an armed revolt. The Russian Empire as a colonizer and oppressor tried to assimilate the Poles and incorporate them into the imperial whole by destroying national specifics and identity. It defeated the first two armed revolts, in 1794 lead by T. Kostiushko and the November revolt of 1830-1831, as the Russians were more skilled in military organization. But they failed to squelch the Poles' dream to revive their own state.

In the meantime, the Empire itself was changing. After it was defeated in the Eastern (Crimean) War of 1853-1856, it started a series of reforms. One of the institutions to be totally reformed was the imperial army. The authorities rejected the former serf model and strove to make it up-to-date, i.e. quality above quantity, reformation of military schools, weapons updating and a totally new principle of territory dislocation - by military districts, what enabled the coalescence of administrative and military powers.

In early 60 -ies of the $19^{\text {th }}$ cent. these two factors fell into historic opposition.

The problem field of the events of 1863-1864 in Right Bank Ukraine goes on attracting scholarly attention. Contemporary Ukrainian 
researchers use archive materials to thoroughly study various aspects of Polish liberation movement and its influence upon social life of the region. Scientific conferences, seminars, discussions of the analyzed issues are held. Among those discussed, military factor has been one of the hotly debated.

The January Revolt happened to be the final stage of the armed struggle of the Poles for state independence in the $19^{\text {th }}$ cent., which served a sphere of sufficient historic research and the events analysis from the political, social and military point of view. Vast source investigation and dozens of publications reflect the results of study in more than a hundred years.

Keywords: Kyiv governor-general authority, social and political situation, January Revolt, Russian Army. 